\title{
DIREITO A TER DIREITOS COMO PERFOMATIVIDADE POLÍTICA: reler Arendt com Butler
}

\author{
André Duarte*
}

\begin{abstract}
Este texto discute o significado da noção de um "direito a ter direitos”, introduzida por Hannah Arendt no contexto de sua análise dos elementos sócio-históricos e políticos que se cristalizaram na forma de domínio totalitária. Num primeiro momento, apresento rapidamente o contexto em que a noção fez sua aparição no interior da obra Origens do totalitarismo. Num segundo momento, apresento a interpretação proposta por Seyla Benhabib para aquele preceito arendtiano, que o situa num plano teórico epistemológico-moral e o refere ao projeto de um cosmopolitanismo neokantiano. Num terceiro momento, argumento a favor de uma leitura propriamente política daquela noção arendtiana, divergindo da leitura de Benhabib. Finalmente, num quarto e último momento, apresento a interpretação proposta por Butler para a noção arendtiana do direito a ter direitos, a qual explicita sua dimensão político-performativa, revelando-se assim sua importância para pensarmos manifestações políticas contemporâneas em um contexto de privação de direitos. Concluo que a interpretação de Butler é mais consoante com o pensamento político de Arendt.

Palavras-chave: Arendt. Direito a ter direitos. Benhabib. Butler. Performatividade política.
\end{abstract}

\section{INTRODUÇÃO}

Há pensadores/as políticos/as cuja genialidade teórica se caracteriza pela construção de obras baseadas numa sólida e sistemática arquitetônica, no interior da qual conceitos bem-fundados se encadeiam de maneira a construir o universo normativo a partir do qual julgamos e avaliamos as situações políticas concretas do mundo. Jürgen Habermas, John Rawls, mas também Norberto Bobbio seriam autores exemplares a esse respeito, como tantos outros mais. Mas também há pensadores/as cuja marca genial se manifesta a partir de noções e intuições poderosas, nem sempre suficientemente exploradas ou explicitadas, frequentemente desprovidas de fundamentos seguros, mas que, entretanto, dão muito que pensar. Tais pensadores/as são aqueles/as que, subitamente, num canto de página ou no decurso de uma entrevista, nos apresentam uma

* Universidade Federal do Paraná UFPR. Departamento de Filosofia. Programa de Pós-Graduação em Filosofia. Programa de Pós-Graduação em Educação.

Rua Dr. Faivre n. 405. Ed. D. Pedro II, 20 andar. Cep: 80060-

120. Curitiba - Paraná - Brasil.

andremacedoduarte@yahoo.com.br

https://orcid.org/0000-0002-8401-0032 noção cujo brilho luminoso nos impele a refletir sobre determinado assunto a partir de uma perspectiva teórica outra. A genialidade sutil de tais pensadores/as reside não apenas no conjunto de sua obra, mas também se manifesta em noções que, a despeito de aparecerem apenas esporadicamente em seus textos, destacam-se no conjunto de sua reflexão e acabam por inspirar debates e discussões que em muito transcendem o contexto teórico imediato ao qual tais noções se encontravam vinculadas. Tais pensadores/as são capazes de provocar o pensamento alheio, isto é, são aqueles/as que nos convidam a pensar junto a eles/as, a preencher com nosso pensamento as lacunas e os silêncios de suas próprias formulações, quando não nos incitam a pensar para além deles/as e até mesmo contra eles/as.

Creio que Hannah Arendt se enquadra nessa última categoria de pensadoras, e para justificar essa consideração gostaria de retomar a sua interessante e enigmática noção a respeito de um "direito a ter direitos", introduzida ao longo das páginas finais de sua análise do "Imperialismo", que integra sua primeira e monumental obra, Origens do Totalitarismo 
(2000), publicada em 1951. Hannah Arendt formulou a noção de um "direito a ter direitos" no contexto de sua avaliação crítica acerca dos paradoxos e insuficiências da Declaração dos Direitos do Homem em face da presença de milhões de migrantes, refugiados e apátridas, os quais se viram desprovidos de um lugar no mundo no período histórico do entre guerras do século XX. Tal fenômeno, de certa maneira, pavimentou o caminho que conduziu às políticas de extermínio levadas a cabo por diversos regimes políticos, alcançando o paroxismo com a chamada Solução Final, preparada e perpetrada pelo nacional-socialismo. Tal noção surge de maneira súbita ao longo de páginas memoráveis, mas Arendt jamais a esmiuçou ou retomou de maneira sistemática ao longo de sua obra, deixando em estado bruto um diamante reluzente, incrustado na rocha magnífica que é o seu livro Origens do Totalitarismo. Posteriormente, tal noção seria retomada, lapidada e burilada por diversos autores, ${ }^{1}$ inspirando reflexões que, por vezes, chegam a conclusões diametralmente opostas e distintas entre si, como é o caso das interpretações propostas por Seyla Benhabib (2005) e Judith Butler (2015).

O propósito deste texto é o de retomar a discussão da noção arendtiana de "direito a ter direitos” levando em consideração, justamente, as interpretações e apropriações propostas por Benhabib e Butler a seu respeito. Num primeiro momento, apresento o contexto original em que a noção fez sua aparição no interior $\rightarrow$ de Origens do totalitarismo. Num segundo mo苛 mento, apresento a interpretação proposta por Seyla Benhabib para aquela noção arendtiana, situando-a num plano teórico epistemológi¿. co-moral que tem por referência o projeto de ले um novo cosmopolitanismo kantiano. Em um $\vec{\circ}$

¿ิ 1 Para uma discussão do "direito a ter direitos" vejam-se: Schaap, A. "Enacting the right to have rights: Jacques Rancière critique of Hannah Arendt". In: European Journal of Political Theory, 10:22, 2011; Ingram, J.: "What is a 'Right to have Rights'? Three images of the Politics of Human Rights". In: American Political Science Review, vol. 102, n. 4,

J Novembro de 2008; Bernstein, R. "Statelessness and the

Right to have Rights". In: Hannah Arendt and the Jewish

Question. Cambridge, Massachusetts, MIT Press, 1996;

Aguiar, O. "Hannah Arendt e o direito", Parte II. In Kriterion, n. 143, agosto de 2019. terceiro momento, argumento a favor de uma interpretação propriamente política daquela noção. Finalmente, num quarto momento, apresento a interpretação proposta por Judith Butler para aquela noção, a qual explicita a dimensão político-performativa que lhe seria inerente. Neste quarto e último momento, também procuro mostrar porque a interpretação proposta por Butler me parece mais consoante com o espírito da reflexão arendtiana acerca da ação política, e exploro, então, sua potencialidade teórica para a compreensão de alguns movimentos políticos do mundo contemporâneo, em particular, aqueles levados a cabo sob circunstâncias de forte privação de direitos.

\section{HANNAH ARENDT E O DIREITO A TER DIREITOS}

A noção de Arendt acerca de um "direito a ter direitos" aparece brevemente no final do subitem 5 da Segunda Parte de Origens do Totalitarismo, intitulado "O declínio do Estado-nação e o fim dos direitos do homem", que conclui a Segunda Parte daquela obra. Ali, Arendt discute o fenômeno do Imperialismo europeu de finais do século XIX e meados do século XX, entendendo-o como um dos elementos que contribuíram para a consolidação da dominação totalitária em sua vertente nazista. Nas páginas que encerram a segunda parte da obra, Arendt ressalta o vácuo institucional produzido pela desestabilização das estruturas políticas, econômicas e sociais europeias após a Primeira Guerra Mundial, enfatizando, sobretudo, a aparição de uma quantidade incalculável de refugiados, minorias e apátridas, isto é, de um imenso contingente populacional destituído de direitos. Ao assumirem escala global, tais fenômenos prenunciaram a ruptura do princípio da igualdade de todos perante as leis, uma das bases de sustentação do antigo estado-nação. Naquele contexto, Arendt sustentou que a ruptura da igualdade de todos perante as leis tinha como consequência a dis- 
solução da nação numa "massa anárquica de indivíduos super e subprivilegiados." (Arendt, 2000, p. 324).

Esse vácuo institucional ensejou a aparição de indivíduos que já não compartilhavam quaisquer laços ou interesses comuns, condição que os transformou em uma massa indistinta e que, pouco depois, engrossaria as fileiras do movimento totalitário ou seria deportada e aprisionada em campos de concentração ou de extermínio. Para a autora, quando massas gigantescas de seres humanos foram consideradas indesejáveis e supérfluas por estados europeus cujas constituições, não obstante, estavam baseadas no princípio dos direitos humanos, revelou-se que, a despeito deles serem "supostamente inalienáveis", tais direitos eram, de fato, "inexequíveis" (Arendt, 2000, p. 327). O problema evidenciado pelas massas de apátridas, imigrantes, minorias e refugiados não era mais apenas a "perda do lar", isto é, a "perda de toda a tessitura social na qual haviam nascido e na qual haviam criado para si um lugar peculiar no mundo", mas se encontrava na própria impossibilidade de encontrar um "novo lar" no mundo (Arendt, 2000, p. 327). Tais massas humanas se viram privadas da proteção legal promovida e garantida por quaisquer Estados, pois tal proteção lhes fora negada nos países em que antes viviam, e tampouco lhes foi garantida nos países para os quais se dirigiram. Tais massas tampouco poderiam recorrer ao direito de asilo, pois não haviam sido expulsas de seus países de origem por motivo de quaisquer convicções políticas ou religiosas.

É no contexto da conclusão de sua análise dos elementos históricos que tornaram possível a cristalização totalitária que Arendt formula sua crítica, a qual se dirige não propriamente aos Direitos Humanos enquanto tais, mas às perplexidades imbricadas em seu fundamento metafísico. De fato, quando Hannah Arendt introduz a noção do "direito a ter direitos" (Arendt, 2000, p. 330 trad. mod.), ela a entende, de saída, em contraponto à ideia metafísica de que os seres humanos, enquanto tais e por si próprios, seriam, desde o seu nascimento, portadores de direitos humanos inalienáveis. Para Arendt, a calamidade da perda de direitos por parte de massas humanas cuja dimensão global era sem precedentes históricos, revelaria que o fundamento dos direitos e, também, o dos Direitos Humanos, não se encontraria numa concepção filosófico-moral acerca do Homem ou da Humanidade tomados em sua individualidade, isto é, enquanto unidade isolada ou singular, não plural, mas sim, na pertença relacional e efetiva a uma comunidade política, em que seja possível agir e discursar de maneira relevante e significativa. Contudo, não parece haver consenso em torno dessa interpretação. Afinal, a despeito de recusar a interpretação clássica, monológica, acerca da noção de fundamento, Seyla Benhabib propõe em sua obra, $O$ direito dos outros (2005), uma interpretação filosófico-moral do preceito arendtiano do "direito a ter direitos" que a refere ao projeto de um novo cosmopolitismo kantiano. Vejamos.

\section{BENHABIB: direito a ter direitos como princípio epistemológico-moral}

Seyla Benhabib interpreta o preceito arendtiano do "direito a ter direitos" no capítulo dois de sua obra, Os direitos dos outros (2005), na qual discute a noção de "pertencimento político" tendo em vista esclarecer os "princípios e práticas" políticas que permitem a "inclusão de estrangeiros, imigrantes e recém-chegados, refugiados e asilados" no interior de "entidades políticas" existentes (Benhabib, 2005, p. 13). Em termos modernos, tal pertencimento político é regulado pelo conceito de "cidadania nacional" atribuída por Estados "soberanos", muito embora tal soberania estatal tenha sido posta em questão por diversos fenômenos políticos, como guerras e movimentos migratórios massivos, de maneira que a noção de "fronteiras da comunidade 
política” tem se mostrado insuficiente para determinar a condição de pertencimento político cidadão (Benhabib, 2005, p. 13).

Em uma palavra, sua preocupação reside em definir princípios normativos que possam nortear uma teoria da "justiça global" e, para tanto, Benhabib recorre a uma releitura do cosmopolitanismo de inspiração kantiana, visando levar em consideração o fenômeno da hospitalidade ou da inclusão cidadã de massas de estrangeiros, migrantes e refugiados, cuja própria existência põe em questão o Estado-centrismo, isto é, o Estado como figura política determinante na regulação da concessão da cidadania e na definição das políticas de proteção das fronteiras. A questão central que anima a reflexão de Benhabib nesse livro é a de que os "movimentos migratórios transnacionais" põem em destaque um "dilema constitutivo" das democracias liberais, qual seja, o dilema "entre as afirmações da autodeterminação soberana, por um lado, e a adesão aos princípios universais dos direitos humanos, por outro.” (Benhabib, 2005, p. 14). Seu propósito é o de levar a cabo uma discussão acerca do "pertencimento político" a partir de uma "reconstrução interna" destes dois elementos que constituem tal dilema político. (Ibidem).

A perspectiva da reconstrução interna visa afastar o que a autora entende ser a solução fácil da recusa do Estado soberano como instância de atribuição da cidadania. De fato, não há solução fácil para aquela tensão constitutiva + das democracias liberais entre as reivindicações 冚 $\mathrm{de}$ de soberania e do respeito aos direitos humanos, e a autora se nega a tomar partido por apenas uma dessas polaridades, considerando que $\dot{2}$ ambas devem ser mantidas, porém, de maneira § revisada. Seguindo "a tradição kantiana do fe-

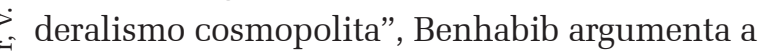
favor do que denomina como o princípio das “adesões democráticas" em entidades estatais que preservam sua soberania no interior de fronteiras determinadas, mas, de maneira que tais adesões possam abranger uma noção de "pertencimento" que exceda as estruturas tra- dicionais dos estados nacionais existentes (Benhabib, 2005, p. 14). Trata-se, pois, de abrir brechas para uma "justiça cosmopolita" no interior de unidades estatais soberanas e, para tanto, a autora diverge das interpretações neokantianas que privilegiam aspectos distributivos e deixam de lado uma discussão mais apurada acerca da noção de "pertencimento justo" (Ibidem, p. 1415). Sua noção de "pertencimento justo" implica o reconhecimento de um "direito moral dos refugiados e asilados a uma primeira adesão"; um "regime de fronteiras porosas para os imigrantes", bem como um "mandato contra a desnacionalização e a perda de direitos de cidadania," além da "reivindicação do direito de todo ser humano a 'ter direitos', quer dizer, a ser uma pessoa legal, com certos direitos inalienáveis, não importando qual seja sua condição de pertencimento político" (Benhabib, 2005, p. 15). É neste contexto teórico que Benhabib recorre à noção arendtiana do "direito a ter direitos".

Em sua interpretação, Benhabib distingue analiticamente as duas figuras do direito que aparecem no enunciado arendtiano. Para a autora, o conceito de direito que aparece no início do enunciado seria de natureza distinta do conceito de direito que aparece ao seu final, de modo que o preceito arendtiano traria implícito consigo dois conceitos de direito articulados entre si, um constituindo o fundamento do outro. O direito enunciado no singular e em primeiro lugar seria um "direito moral" enraizado na própria "humanidade" do ser humano, devendo ser entendido como o fundamento sobre o qual se assentam todos os demais direitos civis e políticos. Inspirando-se na análise proposta por Michelman (1996), Benhabib entende que este direito primeiro constituiria um "imperativo moral" relativo à obrigação de reconhecer todo e qualquer ser humano como pertencente a um determinado agrupamento, isto é, seria o "direito a ser reconhecido pelos demais como pessoa, à qual correspondem direitos em geral” (Benhabib, 2005, p. 50).

Este imperativo estaria amparado no princípio kantiano do reconhecimento da 
humanidade como um "fim em si mesmo", e nunca como meio para algo. Enquanto tal, este direito primeiro e de natureza moral é distinto da noção jurídico-política dos direitos, enunciada em segundo lugar e relativa àqueles direitos e obrigações que correspondem a cada um, tão logo tenham sido efetivamente reconhecidos como pertencentes a um determinado agrupamento humano. Haveria, portanto, um "direito moral ao pertencimento", ao qual se associa a expectativa de certa maneira de tratar os seres humanos como fins em si mesmos, bem como haveria "direitos e obrigações" de caráter civil e legal, isto é, aqueles direitos e obrigações que recaem sobre aqueles/as que já foram reconhecidos/as como de fato pertencentes a uma "comunidade legal" (Benhabib, 2005, p. 50-51). Enquanto o direito moral que fundamenta a atribuição de direitos jurídico-civis está assentado na noção de "humanidade", restando "aberto e indeterminado" quem é a pessoa portadora desse direito, os direitos jurídico-civis são direitos atribuídos a seres humanos que já foram reconhecidos como pertencentes a uma "comunidade humana organizada” (Ibidem, p. 51). Segundo Benhabib, "A assimetria entre os usos primeiro e segundo do termo 'direito' deriva da ausência, no primeiro caso, de uma comunidade jurídico-civil de co-sócios, que estejam em uma relação de dever recíproco" (Ibidem).

De fato, Arendt considerou que, se no século XVIII, a humanidade fora entendida como um ideal regulador, em sentido kantiano, no século XX a humanidade teria se tornado um "fato inelutável" (Arendt, 2000, p. 332). Assim, poder-se-ia supor que a humanidade bem pudesse vir a assumir o papel de um novo fundamento para o direito, no sentido de que o "direito a ter direitos, ou o direito de cada indivíduo de pertencer à humanidade, deveria ser garantido pela própria humanidade" (Ibidem). Contudo, esta breve suposição caracterizada pelo uso do condicional é imediatamente posta em suspenso pela própria Arendt, que, logo a seguir, afirma, de maneira peremptória, que "Nada nos assegura que isso seja possível"
(Arendt, 2000, p. 332). Tal desconfiança, por certo, em nada invalida a proposição filosófico-moral da humanidade como fundamento filosófico para um futuro direito cosmopolita dos povos. Entretanto, não é esta a posição teórica defendida por Arendt, que via com desconfiança o gesto teórico que subsume as relações políticas a posições normativas em sentido forte e fundante, apartadas de uma atenta consideração acerca das realidades e experiências políticas concretas, como, ademais, o reconhece a própria Benhabib (2005, p. 52). Arendt chegou mesmo a ponderar que tal fundamento humanitário poderia se tornar profundamente perigoso, caso um dia viesse a ser implementado. O risco temido pela autora era o de que "uma humanidade altamente organizada e mecanizada chegue, de maneira democrática - isto é, por decisão da maioria à conclusão de que, para a humanidade como um todo, convém liquidar certas partes de si mesma" (Arendt, 2000, p. 332).

Meu propósito aqui não é debater a pertinência teórica da concepção neokantiana de justiça cosmopolita defendida por Benhabib, nem tampouco debater seus inúmeros pressupostos filosóficos (Frateschi, 2014), mas, propor uma interpretação política para o preceito arendtiano do "direito a ter direitos". Uma interpretação política daquele preceito há de considerar que as lutas políticas pela conquista do direito de cidadania ou de pertencimento a uma comunidade política, assim como as lutas pela defesa e ampliação de direitos dos cidadãos, não se encontram numa relação de subordinação a um fundamento conceitual, ou a um conjunto de princípios filosóficos e morais, de caráter universal. Tal argumento, contudo, não significa invalidar tais fundamentos e princípios universais, nem tampouco desconsiderar que eles constituem importante fonte de inspiração para aquelas lutas. Uma interpretação política do "direito a ter direitos" afirma a potência política da demanda por direitos humanos universais a partir das próprias lutas políticas pela conquista do direito 
de cidadania, e de todos os demais direitos a ele vinculados. Nesse sentido, tratar-se-ia justamente de inverter a proposição de Benhabib e de deslocar a ênfase de sua discussão sobre o fundamento conceitual na direção de uma análise da própria dinâmica das reivindicações e lutas políticas, as quais já são sempre lutas que incorporam a demanda por direitos humanos. Para tanto, será preciso relacionar o preceito do "direito a ter direitos" com a análise arendtiana acerca da dinâmica da ação política coletiva, aspecto central da reflexão de Arendt em A Condição Humana, obra publicada em 1958.

\section{POR UMA INTERPRETAÇÃO POLÍ- TICA DO DIREITO A TER DIREITOS}

Penso que o "direito a ter direitos" não é entendido por Arendt como uma "reivindicação moral fundamental”, segundo os termos propostos por Benhabib (2005, p. 57), mas como o próprio princípio político da cidadania, pois se refere à condição de "pertencer a algum tipo de comunidade organizada" em que se possa agir e discursar publicamente, e em que cada um seja "julgado pelas ações e opiniões” professadas (Arendt, 2000, p. 330). Numa formulação bastante enfática, a autora chega mesmo a afirmar que o problema crucial não seria a perda de quaisquer direitos específicos, ou mesmo a perda dos chamados direitos humanos, mas, sim, "a perda de uma comuni+ dade disposta e capaz de garantir quaisquer diఫै reitos" (Ibidem, p. 331). A compreensão dessa ¿ tese arendtiana de que o "direito a ter direitos" $\neg$ diz respeito ao pertencimento a uma comuni$\therefore$ dade, na qual a garantia e a defesa dos direitos § se relaciona à possibilidade de agir e discursar politicamente, supõe distinguir diferentes níveis de argumentação: um nível filosófico-político e um nível mais propriamente político, ambos interligados entre si. Ao formular o preceito do "direito a ter direitos", Arendt propõe um argumento de caráter filosófico-político, que recusa a fundamentação metafísica dos direitos humanos em um conceito solipsista, não-relacional, acerca do Humano ou da Humanidade, e de sua dignidade intrínseca.

Contudo, a plena compreensão do sentido político deste preceito pressupõe considerar, ainda, outros dois argumentos de natureza propriamente política: um primeiro argumento, em vista do qual Arendt vincula o preceito do "direito a ter direitos" ao horizonte de pertencimento a uma comunidade política organizada; e, de maneira suplementar, um argumento relativo à caracterização do que seja uma comunidade política organizada. Se lermos o preceito do "direito a ter direitos" em conexão com as reflexões de Arendt sobre a ação e o discurso político, em A Condição Humana - e tal leitura se justifica, visto que já em Origens do Totalitarismo ela entendia a cidadania como vinculada à capacidade de agir e discursar coletivamente - veremos que a autora não restringe a noção do pertencimento a uma comunidade política organizada àquela situação jurídico-política, na qual um grupo humano encontra-se previamente reconhecido como sujeito de direitos por uma entidade estatal soberana. Por outro lado, a reflexão de Arendt sobre a ação e o discurso político, permite interpretar o preceito do "direito a ter direitos" como extensível às formas não-estatais e não convencionais de organização e reivindicação política coletiva, como é o caso das lutas pela inclusão dos não-cidadãos no interior das regras jurídico-políticas que definem a vigência da condição de pertencimento cidadão, aspecto enfatizado por Judith Butler em sua interpretação do "direito a ter direitos" como princípio político-performativo.

Vejamos, primeiramente, como Arendt argumenta no nível filosófico-político. Para a autora, os Direitos do Homem não deveriam ser entendidos como fundados em um conceito metafísico acerca da Humanidade e de sua dignidade intrínseca. Vale dizer, Arendt não compreende a noção acerca do "direito a ter direitos" por referência a categorias filosófico-morais do século XVIII, "pois estas presu- 
mem que os direitos emanam diretamente da 'natureza' do homem (...). O fator decisivo é que esses direitos, e a dignidade humana que eles outorgam, deveriam permanecer válidos mesmo que um ser humano seja expulso da comunidade humana” (Arendt, 2000, p. 331). Ora, justamente esse pressuposto foi demonstrado como insustentável, em face das calamidades políticas do entre guerras do século XX, com suas multidões de refugiados, migrantes, minorias desprotegidas e apátridas, para não mencionar o horror dos campos de extermínio, postos em ação pelo totalitarismo nazista. Para a autora, "O homem pode perder todos os chamados Direitos do Homem sem perder a qualidade essencial de homem e sua dignidade humana" (Arendt, 2000, p. 331), como bem o demonstraram todos/as aqueles/as que, na clandestinidade e, muitas vezes, desprovidos/ as de quaisquer direitos, se engajaram no movimento de resistência à dominação totalitária.

Por outro lado, contudo, estar privado do pertencimento a uma "comunidade política" onde nossos atos e palavras possuam relevância, ou seja, estar totalmente impossibilitado de agir e discursar politicamente, condição partilhada, por exemplo, pelos milhões de seres humanos aprisionados nos campos de concentração e de extermínio, isto sim equivaleria ao mesmo que estar expulso da "humanidade", perdendo-se, consequentemente, toda e qualquer dignidade (Arendt, 2000, p. 331). Para a autora, portanto, o que confere humanidade e dignidade ao ser humano é o fato de encontrar um lugar no mundo onde os próprios atos e palavras tenham relevância e significação políticas, este sendo o princípio a partir do qual ela entende o significado mesmo da cidadania, para além de uma definição estritamente jurídica daquele título. Estar privado do "direito a ter direitos", entendido como a raiz política de uma cidadania definida como capacidade de agir e discutir politicamente, é estar privado, também, não apenas de todo e qualquer direito suplementar, de que o cidadão possa se beneficiar, mas, sobretudo, significa o mesmo que estar reduzido à "abstrata nudez de ser unicamente humano e nada mais" (Ibidem). Mas, se o fundamento do "direito a ter direitos" não reside num conceito metafísico de humanidade, estaria tal fundamento radicado na história das tradições locais, ou no vínculo entre estado, nação e território?

Se Arendt não endossa a ideia filosófica moderna, de matiz kantiano, de que as relações políticas devam estar subsumidas a princípios filosóficos ou morais de natureza extra-política, como a Humanidade do ser humano, cabe observar que sua rápida menção à crítica de Burke (2014) à formulação universal abstrata dos Direitos do Homem, elaborada por ele já no decorrer da Revolução Francesa, não faz da autora uma defensora das peculiaridades históricas vinculadas aos contextos locais e historicamente particulares, nem faz dela uma defensora do princípio da soberania estatal, com base na territorialidade e na nacionalidade. Arendt não defende o preceito de Burke acerca dos direitos históricos dos ingleses ou de quaisquer outros povos, em sua reflexão crítica sobre as perplexidades dos direitos humanos, visto que tal preceito assume para ela apenas "validade pragmática” (Arendt, 2000, p. 333) e não validade teórica como fundamento de natureza historicista para a formulação e garantia de quaisquer direitos. Por certo, ela reconhece que, durante o entre guerras, e logo após a segunda grande guerra, "não apenas a perda de direitos nacionais levou à perda dos direitos humanos, mas a restauração desses direitos humanos, como demonstra o exemplo do Estado de Israel, só pôde ser realizada até agora pela restauração ou pelo estabelecimento de direitos nacionais" (Arendt, 2000, p. 333). Entretanto, o que lhe importava não era a defesa dos valores e tradições históricos como fundamento da atribuição, validade e garantia dos direitos, nem tampouco argumentar que somente poderia haver direitos nacionais resguardados por estados-nação soberanos. Sobretudo, não se tratava de retomar a defesa da tese acerca de um vínculo indissolúvel 
entre estado, nação e direito, uma vez que Arendt estava ciente das limitações inerentes ao sistema do estado-nacional, demonstradas, cabalmente, com a ruptura da estrutura social, política e econômica dos estados-nacionais, em meio às agruras da crise econômica do entre guerras e, mais ainda, durante os anos de dominação totalitária e sua política de extermínio em escala de massas.

O fenômeno da multiplicação exponencial de apátridas, migrantes, refugiados e minorias desprotegidas mostrara à autora que o vínculo entre nação, Estado, território e direito já não poderia mais constituir um fundamento sólido para o direito, do mesmo modo como tampouco faria sentido voltar a recorrer à "suposta existência de um ser humano em si" como fundamento do direito. Afinal, recorda Arendt, nos momentos de maior urgência política, "o mundo não viu nada de sagrado na abstrata nudez de ser unicamente humano" (Arendt, 2000, p. 333). Ou seja, o recurso pragmático ao argumento de Burke não leva Aren$\mathrm{dt}$ a defender os direitos ou privilégios associados à história dos povos, mas, opera como contraste heurístico, que revela a exigência de repensar a relação entre direito, natureza e política no mundo contemporâneo: "Parece que o homem que nada mais é que um homem perde todas as qualidades que possibilitam aos outros tratá-lo como semelhante" (Arendt, 2000, p. 334). Contudo, cabe perguntar: o que significa a menção arendtiana à "abstrata nudez de s ser unicamente humano e nada mais" (Ibidem, p. 331)? Como compreender o sentido da afirmação de que "o homem que nada mais é que $\neg$ um homem perde todas as qualidades que pos$\dot{2}$ sibilitam aos outros tratá-lo como semelhanल

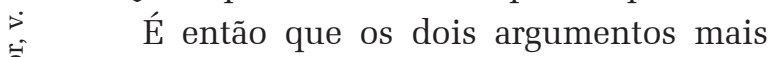
propriamente políticos de Arendt se tornam importantes para a compreensão do sentido do seu preceito quanto ao "direito a ter direitos". Como dissemos anteriormente, os argumentos de Burke assumiram para Arendt "novo significado" diante da realidade concreta da- queles/as que "foram expulsos de toda comunidade política” (Arendt, 2000, p. 334) no período do entre guerras. Aqui, é crucial atentar para o fato de que a argumentação de Arendt é propositadamente inespecífica ao mencionar o termo "comunidade política", que permanece indeterminado. Essa indeterminação parece cumprir duas funções na reflexão arendtiana: por um lado, essa indeterminação abre espaço para se refletir sobre o caráter artificial da comunidade política; por outro lado, ela também abre espaço para uma reflexão política que não restringe o exercício da cidadania à jurisdição do Estado, nem, muito menos, ao conceito de estado-nacional, com sua carga de natureza e naturalidade, estabelecida a partir da vinculação entre direito e nascimento, num dado território governado por um poder soberano. De fato, mesmo que Arendt não tenha dirigido o impulso de sua reflexão na direção de uma recusa absoluta da figura do Estado como instância de atribuição e garantia de direitos, há diversas passagens em seus textos que deixam clara sua crítica à redução da política e da cidadania ao âmbito estatal e aos laços de naturalidade, motivo pelo qual jamais concordou com a criação de Israel como estado-nacional judeu, às expensas da população árabe da Palestina. Vários textos recolhidos na coletânea The Jew as Paraiah (1978) mostram que Arendt sempre foi crítica em relação às correntes prevalecentes do sionismo, estando ciente do caráter problemático das bases de fundação do Estado de Israel como estado-nacional judeu, visto considerar que, tal condição, implicaria o rebaixamento da população árabe que vivia e vive na Palestina, à condição de cidadãos de segunda categoria, e mesmo à condição de não-cidadãos.

Mas, voltemos à figura indeterminada da comunidade política no pensamento de Arendt. É justamente essa indeterminação que lhe permite refletir sobre a comunidade política como aquilo que resulta do "artifício humano" (Arendt, 2000, p. 334), isto é, como "produto" ou invenção artificial, construída por atos e palavras, por meio dos quais os seres humanos 
se dão condições igualitárias, que eles jamais podem encontrar como dadas no âmbito da natureza. Arendt formulou sua concepção acerca da artificialidade do direito e da política, no contexto desolador da redução do ser humano, nos campos de concentração dos regimes totalitários, à condição natural de simples membros da espécie humana, com seus atributos e distinções naturais. Aliás, o nazismo fez justamente da natureza, do sangue e da hereditariedade os elementos decisivos para a determinação da condição privilegiada ou desprivilegiada de milhões de seres humanos. Para a autora, a meta dos regimes totalitários foi a de reduzir homens e mulheres a seu mínimo denominador comum natural, privando-os de seus direitos políticos e de sua dignidade, ao deportá-los e aprisioná-los em laboratórios infernais, para então exterminá-los. Daí deriva sua oposição entre natureza e artifício político, expressa de maneira contundente na seguinte afirmação:

A igualdade, em contraste com tudo o que se relaciona com a mera existência, não nos é dada, mas resulta da organização humana, porquanto é orientada pelo princípio da justiça. Não nascemos iguais; tornamo-nos iguais como membros de um grupo por força da nossa decisão de nos garantirmos direitos reciprocamente iguais. Nossa vida política baseia-se na suposição de que podemos produzir igualdade através da organização, porque o homem pode agir sobre o mundo comum e mudá-lo e construí-lo juntamente com os seus iguais e somente com os seus iguais (Arendt, 2000, p. 335).

Arendt estabelece aqui uma inversão do postulado filosófico moderno, de inspiração cristã, de que todos os homens nascem livres e iguais entre si, a fim de enfatizar que a igualdade não é um dado da natureza, mas, sim, uma conquista política, um constructo que depende da organização e da decisão coletiva, no sentido de que a igualdade precisa ser afirmada e posta em ação. Tal decisão e afirmação, portanto, vinculam-se às palavras e ações oriundas de uma pluralidade de agentes que se orientam pelo princípio da justiça, de sorte que o mundo comum, que assim é cole- tivamente construído, se veja sujeito a transformações derivadas das ações e palavras subsequentes de outros cidadãos. Por outro lado, Arendt considera que as populações ou grupos humanos que são impedidos de participar do mundo político comum veem-se reduzidos à sua "elementaridade natural, à sua mera diferenciação" (Arendt, 2000, p. 335). Quem está privado/a do reconhecimento de sua condição de igualdade, pensa Arendt, está privado/a do exercício da cidadania e, assim, também do exercício e usufruto de quaisquer direitos.

Certamente, está sujeito à crítica o modo eurocêntrico e, por vezes, mesmo ingênuo, pelo qual Arendt reafirma a tradicional oposição filosófica entre estado civil e estado de natureza. A partir dela, Arendt delineia uma distinção simplista entre civilizados e selvagens, a qual desconsidera as pesquisas etnológicas que, já à época de formulação e redação de Origens do Totalitarismo, haviam compreendido que as coletividades ditas primitivas também constroem um mundo e uma cultura, que as qualifica e diferencia em relação ao ambiente e aos demais seres naturais, em meio aos quais vivem. Temos aqui uma versão claramente problemática de suas distinções entre natureza e política, espaço privado e espaço público, entre o âmbito da necessidade e o da liberdade, em vista das quais, a autora afirma que tudo aquilo que provém da "esfera do que é meramente dado," e que, nas sociedades civilizadas, é relegado à "vida privada", deve ser visto como uma "permanente ameaça à esfera pública, porque a esfera pública é tão consistentemente baseada na lei da igualdade como a esfera privada é baseada na lei da distinção e da diferenciação universal" (Arendt, 2000, p 335).

O problema dessa afirmação reside na ideia de que a própria fronteira entre os âmbitos público-político e o privado não esteja sujeita à transformação, em decorrência do agir político coletivo, possibilidade que a própria Arendt não deixou de reconhecer em outras ocasiões. Em um debate ocorrido em 1972, quando questionada justamente acerca da ri- 
gidez de sua distinção entre público e privado, Arendt respondeu que

Em todas as épocas, as pessoas que vivem coletivamente terão assuntos que pertencem ao espaço público - coisas 'que são dignas de ser discutidas em público’. O que são esses assuntos em cada momento histórico é provavelmente totalmente diferente. (...) Então, o que se torna público (what becomes public) em cada período dado parece ser para mim totalmente diferente (Arendt,1979, p. 316).

Do contrário, tornar-se-ia impossível pensar, em termos arendtiano, a politização de questões que, ao adentrarem o espaço público, não levaram a uma contaminação perigosa do espaço público pelo privado, mas, sim, a um enriquecimento e a um entendimento mais complexo acerca da composição histórica do espaço público, bem como acerca da própria redefinição da distinção entre espaço público e espaço privado (Duarte, 2016). Afinal, tudo aquilo que, durante séculos, permaneceu relegado ao plano privado, ao ser transformado em objeto de ação e discurso coletivos, necessariamente se politiza e se transforma, alterando seu antigo status. $\mathrm{O}$ que, por certo, não quer dizer que as distinções entre público e privado, política e natureza, liberdade e necessidade, não tenham qualquer validade. Afinal, a afirmação taxativa de que tudo é político leva necessariamente à dissolução de toda e qualquer fronteira e, assim, dissolve a própria ideia de política. Tudo depende, portanto, do modo como tais distinções são postas em operação (Honig, 1995).

No entanto, tampouco se pode desconsiderar as importantes implicações políticas contidas na tese arendtiana de que, aqueles/as que decidem se reunir politicamente, põem em marcha o exercício da cidadania e, nesse mesmo momento, se constituem como membros iguais de uma comunidade política, forjando um mundo comum, sob a égide do princípio da justiça. Exatamente aqui surge o segundo argumento político implicado no preceito arendtiano do "direito a ter direitos", pois, a comunidade política, neste sentido amplo e indeterminado, não se restringe ao Estado ou a qualquer instância governamental, mas é aquilo que se constitui, ou que resulta, das ações e palavras coletivas, que qualificam politicamente os seres humanos como iguais. Este é um aspecto crucial do pensamento arendtiano e que, infelizmente, apenas raramente tem sido observado pelos seus intérpretes. Estão contidas nesse argumento político arendtiano diversas implicações relevantes para a análise da potência política dos novos movimentos sociais, aspecto ressaltado por Judith Butler (2015). Recorde-se a formulação arendtiana, citada anteriormente, de que somente nos tornamos iguais enquanto membros de um agrupamento humano, na medida em que decidimos nos atribuir e nos garantir direitos reciprocamente iguais. Ou seja, a igualdade resulta da decisão humana, é um produto da ação e do discurso políticos. Em momento algum, como se percebe, Arendt relaciona a vida política à condição prévia de já ser membro cidadão reconhecido por um Estado soberano. Para Arendt, o que está em questão é o mecanismo político pelo qual os/as agentes atribuem-se e garantem-se a si mesmos/as direitos iguais, não importando, aqui, se tais direitos já se encontram protegidos por alguma instância estatal. Cada agente político/a que se engaja num determinado curso de ação, em condições de respeito da pluralidade, e orientando-se pelo princípio da justiça, atribui-se a si, e aos demais, direitos reciprocamente iguais.

Assim, a formulação arendtiana é vaga o suficiente ao referir-se apenas à noção de pertencimento a um "grupo", o que, por certo, bem pode valer para aqueles/as que se engajam em movimentos sociais visando à ampliação de seus direitos, ou mesmo visando à sua própria inclusão no domínio jurídico da cidadania. A igualdade é indissociável do exercício da liberdade política, pois é em condições de igualdade que podemos agir e transformar o mundo e suas estruturas institucionais. Em Who sings the Nation-State (2010) e, sobretu- 
do, em Notes toward a performative theory of assembly (2015), Butler segue exatamente essa linha de raciocínio e, a partir dela, constrói sua interpretação da noção arendtiana do "direito a ter direitos", enfatizando seu poder performativo, isto é, sua capacidade de produzir efeitos de cidadania, pela ação coletiva de populações subalternizadas que lutam por condições de uma vida vivível.

\section{BUTLER: a interpretação político- -performativa do direito a ter direitos}

Contrariamente a certos aspectos problemáticos do pensamento político de Hannah Arendt, Judith Butler entende que não é possível deixar de considerar o papel dos corpos e de suas necessidades quando se trata de pensar a ação e o discurso políticos. Butler reitera e retoma, deste modo, as diversas críticas formuladas por pensadoras do feminismo quanto à distinção arendtiana entre os assim chamados movimentos políticos, levados a cabo em nome da liberdade, e os movimentos sociais, que seriam ditados pela premência da necessidade e, assim, seriam supostamente não-políticos, como se o âmbito do corpo e das necessidades constituísse o campo da não-liberdade: "Se o corpo permanece no nível da necessidade, então pareceria que nenhuma consideração política da liberdade poderia ser incorporada" (Butler, 2015, p. 47). Ao considerar o caráter corporal e incorporado do exercício da liberdade, Butler desmonta a distinção arendtiana entre liberdade e necessidade, e defende o caráter propriamente político da luta coletiva contra a desigual distribuição mundial da necessidade: "Apenas no contexto de um mundo vivo emerge o homem como criatura que age, um homem cuja dependência para com outros e para com os processos vivos faz emergir sua própria capacidade para a ação”. Neste sentido preciso, portanto, "Viver e agir estão vinculados, de tal maneira que as condições que tornam possível para qualquer um viver, são parte do próprio objeto da reflexão política e da ação" (Butler, 2015, p. 44).

Estabelecida essa divergência de fundo, vejamos como Butler interpreta e se apropria do lema arendtiano do "direito a ter direitos". Como vimos, uma das teses fortes que Arendt defende é a de que as populações ou grupos humanos que são impedidos de participar do mundo político comum veem-se reduzidos à sua "elementaridade natural, à sua mera diferenciação" (Arendt, 2000, p. 335). Assim, aqueles/as que estão privados/as da capacidade de agir e falar pública e coletivamente, estão privados/as da possibilidade de reconhecerem-se como iguais, isto é, estão privados/ as do exercício da cidadania e, também, do usufruto de todos os direitos a ela associados. Ora, esta ideia tem como correlato a tese de que aqueles/as que decidem se reunir politicamente põem em marcha, justamente, exercício da cidadania, e, nesse instante, se constituem como membros iguais de uma comunidade, no sentido de que produzem a igualdade recíproca, ao agirem inspirados pelo princípio da justiça, verdadeiro motor do engajamento político democrático. Eis, então, como Butler relê a conexão entre essas duas teses arendtianas: Nos termos de Arendt, podemos dizer que ser ex-
cluído do espaço da aparência, ser excluído de fazer
parte da pluralidade, que traz o espaço da aparência
ao ser, é ser privado do direito a ter direitos. A ação
plural e pública é o exercício do direito ao lugar e ao
pertencimento, e este exercício é o meio pelo qual
o espaço das aparências é pressuposto e trazido à
existência (Butler, 2015, p. 59-60).

Estar impedido de agir e discutir publicamente é o mesmo que estar privado/a de liberdade e de igualdade, visto que ambas somente se atualizam no espaço das aparências, que constitui um mundo comum entre os/as agentes políticos/as. Liberdade, igualdade e cidadania não são conceitos abstratos para Arendt, mas somente se constituem na medida em que os/as agentes políticos/as podem agir e discutir entre si, seja num espaço público previamente delineado, seja por meio da própria 
criação de um espaço público paralelo ou mesmo clandestino, quando situações políticas emergenciais se apresentam. Por outro lado, agir e discursar politicamente, mesmo quando não se está de posse de um título jurídico que qualifique o/a agente como cidadão/ã de direito, é o mesmo que pôr em ação a liberdade política e a igualdade recíproca, produzindo-se, assim, um efeito político de cidadania. Assim, a tese interessante que Butler defende em sua interpretação da noção arendtiana do direito a ter direitos enfatiza o seu poder performativo, isto é, a sua capacidade de produzir efeitos de igualdade e de cidadania por parte das populações subalternizadas, exatamente no instante em que lutam para conquistar os direitos de que carecem. Deste modo, Butler entende que o pensamento de Arendt nos oferece importantes indicações acerca de como o reunir-se e o associar-se agem de maneira a estabelecer ou reestabelecer "o espaço da aparência”, entendido como espaço constituído pelo "caráter corporal da ação humana plural” (Butler, 2015, p. 48). Para Butler, portanto, "Talvez um dos propósitos aqui seja o de tentar repensar essas distinções arendtianas para mostrar que o corpo, ou, antes, a ação corporal concertada (...) pode dar sentido aos princípios da liberdade e da igualdade" (Butler, 2015, p. 48).

Para Butler, o "direito a ter direitos" é um "tipo de exercício performativo," no sentido de que se trata de algo que se exerce, e não de um ato para o qual se requeira um fundamento exterior à própria ação política que demanda direitos. Esta reivindicação performativa pelo "direito a ter direitos" não é, porA tanto, "puramente linguística", nem tampouco ¿. assume caráter epistemológico-moral; antes, ஓ tal reivindicação é política, e se leva a cabo por meio do "movimento corporal, de assembleias, de ação e resistência” (Butler, 2015, p. 49). Assim, contrariamente à interpretação proposta por Benhabib, segundo a qual a noção arendtiana do "direito a ter direitos" seria um "imperativo moral dirigido a todos os homens indistintamente (à humanidade enquanto tal)"
(Benhabib, 2005, p. 50), Butler a entende como insígnia dotada da capacidade performativa de produzir, em ato, aquelas condições das quais os/as agentes se encontram privados/as. Este efeito performativo de instauração em ato daquilo de que se carece, no contexto imediato do próprio curso da ação coletiva, é entendido como a condição política primeira para que, posteriormente, tal clamor e apelo políticos, venham a conquistar materialidade institucional e positiva nos códigos jurídicos. A eficácia política do "direito a ter direitos" não dependeria, então, de sua cuidadosa fundamentação moral na dignidade intrínseca do Homem ou da Humanidade, mas dos efeitos políticos performativos produzidos pelas próprias lutas, estas sendo as instâncias privilegiadas para a geração de direitos. Para Butler, demandar direitos quando se está desprovido deles

Significa reivindicar aquele mesmo poder de que se está privado, a fim de expor e de militar contra aquela denegação. (...) algumas vezes é uma questão de agir e, ao agir, reivindicar o poder de que se necessita. Isto é a performatividade como a entendo, bem como é, também, uma maneira de agir a partir e contra a precariedade (Butler, 2015, p. 58).

A autora observa ainda que o direito de aparecer publicamente está regulado por normas e esquemas regulatórios que estabelecem quem pode, e quem não pode aparecer em público impunemente, isto é, sem correr riscos de violência. Por isto, toda reivindicação pelo direito universal de aparecer em público está perpassada por formas de poder que estabelecem diferenças que qualificam tal aparição. Deste modo, quando se trata dos/as que não têm direito à franca aparição pública, o seu próprio aparecimento, e suas alianças para tornarem-se visíveis, assumem um caráter decisivo, e isso "envolve a afirmação plural e performativa de uma elegibilidade, ali mesmo onde ela não existia antes" (Butler, 2015, p. 50). Os efeitos dessa afirmação plural e performativa não procuram definir apenas um lugar para aqueles/as que haviam sido desprezados/as, e se encontravam em clara situação precária, 
mas, sobretudo, visam a "produzir uma rachadura no interior da esfera da aparência, expondo a contradição pela qual sua reivindicação de universalidade é afirmada e tornada nula" (Butler, 2015, p. 50). Em suma, a entrada no espaço das aparências daquelas populações que não têm franqueado o seu acesso à visibilidade, depende de uma "crítica das formas diferenciais de poder, pelas quais aquela esfera é constituída, bem como depende de "uma aliança crítica formada entre aqueles que não contam, os inelegíveis - os precários - a fim de estabelecer novas formas de aparência, que busquem superar aquela forma diferencial de poder" (Ibidem, p. 50-51).

Inspirando-se em Arendt, Butler considera que os agrupamentos que agem politicamente, formulam suas demandas coletivas não apenas em nome da igualdade de direitos, ou da igualdade de tratamento, mas que agem e enunciam suas demandas nos próprios termos da igualdade, isto é, se assumem, na prática de suas ações e discursos, "como um agente de igual valia com outros” (Butler, 2015, p. 52). Assim, toda comunidade ou coletividade política que se reúne publicamente, e passa a agir em nome da igualdade, da liberdade e da justiça, estabelece uma oposição crucial para com os significados tradicionais, ou hegemonicamente estabelecidos numa dada sociedade, a respeito do que sejam igualdade, liberdade e justiça. Para Butler,

A igualdade é uma condição e um caráter da própria ação política, ao mesmo tempo em que é, também, a sua meta. Exercer a liberdade não é algo que vem de você ou de mim, mas vem daquilo que está entre nós, do vínculo que constituímos no momento em que exercemos a liberdade conjuntamente, liame sem o qual não há qualquer liberdade (Butler, 2015, p. 52).

Butler entende que Arendt, ao relacionar o "direito a ter direitos" à figura política de uma cidadania que se constrói em atos e palavras, não a limita ao plano da soberania ou dos códigos jurídicos estabelecidos. Extrapolam-se, assim, as fronteiras jurídico-políticas institucionais e burocráticas, a partir das quais um Estado determinado define os limites da cidadania e quem é portador/a de direitos. Isto não significa que Arendt espose um cosmopolitismo jurídico ideal e desencarnado, mas que a capacidade humana para agir e discursar coletivamente, pode se dar em uma multiplicidade de espaços e contextos mundanos, excedendo-se os limites da concepção da cidadania como direito positivado e garantido por um estado soberano, bem como extrapolando-se os limites da política representativa, centrada exclusivamente nos partidos políticos. É por isso que Butler ressalta que a ação performativa, operada pelo "direito a ter direitos", independe "da existência de qualquer organização política particular para sua legitimidade” (Butler, 2015, p. 80), bastando que haja cidadãos que se reúnam na modalidade da ação e do discurso concertados.

De fato, em A Condição Humana (1989), Hannah Arendt defendera a ideia de que a política e o poder surgem originariamente do "espaço da aparência", que passa a "existir sempre que os homens se reúnem na modalidade do discurso e da ação" (Arendt, 1989, p. 199). Trata-se, aí, de um espaço comum que "precede toda e qualquer constituição formal da esfera pública e as várias formas de governo," e cuja própria existência depende, apenas, de que os/as agentes permaneçam juntos/as e dispostos/as a agir e a falar entre si, desaparecendo assim que se isolem uns/mas dos/as outros/ as. Nesse sentido, trata-se também de um espaço comum, até certo ponto intangível, e que existe apenas potencialmente, isto é, enquanto possibilidade, nunca necessariamente ou para sempre. Por isso, Arendt também afirmava que "a polis, a rigor, não é a cidade-estado em sua localização física; é a organização do povo tal como ela desponta do agir e falar conjuntos, e seu verdadeiro espaço se encontra entre as pessoas que vivem em conjunto para esse propósito, não importa onde estejam" (Arendt, 1989, p. 198). Se estabelecermos uma conexão entre a concepção arendtiana da polis, como dimensão política instaurada pela ação e pelo 
discurso, com sua noção acerca do "direito a ter direitos", podemos então compreender que, tal direito, precede qualquer codificação legal e é independente de qualquer apelo a um direito natural. Ele não está fundamentado num conceito moral ou político de humanidade, mas depende de um conjunto de agentes que reivindiquem politicamente o direito de que se encontram desprovidos:

O direito ganha existência quando é exercido, e quando exercido por aqueles que agem em concerto, em aliança. Aqueles que são excluídos da política existente, aqueles que não pertencem a um estado-nação, ou a qualquer outra formação estatal contemporânea, podem ser considerados 'irreais' apenas por aqueles que tentam monopolizar os termos da realidade. E, no entanto, mesmo depois que a esfera pública foi definida por meio de sua exclusão, ainda assim, eles agem. Ainda que tenham sido abandonados à precariedade, ou deixados à morte por meio da negligência sistemática, a ação concertada ainda emerge de seu agir conjunto. E isto é o que vemos, por exemplo, quando trabalhadores sem documentação se reúnem nas ruas, sem qualquer direito legal para fazê-lo (...) (Butler, 2015, p. 80-81).

Em seu diálogo com Spivak, publicado sob o título de Who sings the Nation-State (2010), Butler já dera os primeiros passos para a formulação da sua noção de performatividade política, ao discutir a noção arendtiana do "direito a ter direitos". Desde então, ela a entendia não como princípio normativo abstrato e pertencente ao indivíduo isolado, mas como princípio performativo, próprio à ação política coletiva no espaço público, por meio da qual agentes desprovidos/as de cidadania, põem em exercício uma liberdade política que, justamente, caracteriza a condição do/a cidadão/ã. Ao transplantar sua anterior noção de performatividade de gênero, para o campo dos movimentos políticos de resistência à opressão, Butler logrou pensar práticas políticas que não pressupõem um sujeito identitário ou substancializado, pois não dependem de uma concepção essencialista do sujeito, e nem mesmo da formulação de um conjunto de princípios éticos e políticos de caráter normativo e abstrato, capazes de fundar e orientar, em sentido forte, as ações dos/as agentes. Afinal, o importante aqui é, justamente, a consideração dos efeitos políticos derivados da ação corporal e discursiva, que reivindica direitos. Em se tratando de reivindicações por direitos fundamentais por parcelas da população maximamente expostas à precariedade, em função da carência de políticas de proteção e garantia das condições que tornam uma vida digna e vivível, o conceito de performatividade política permite à autora abrir mão do conceito de sujeito de direitos e, ainda assim, considerar os efeitos políticos implicados nas formas de ação e de reivindicação por direitos, postas em prática por trabalhadores imigrantes ilegais, desprovidos de documentação e de cidadania jurídico-política. Não por acaso, Butler propôs sua primeira interpretação do preceito de Arendt sobre o "direito a ter direitos" ao refletir sobre as grandes manifestações de imigrantes ilegais, de origem latina, ocorridas na Califórnia em meados dos anos 2000. O ápice performático daquelas manifestações públicas consistia em cantar o hino nacional norte-americano em espanhol, demonstrando-se, assim, a complexidade da relação entre a comunidade latina e os Estados-Unidos. Nestas manifestações políticas, a comunidade latina reivindicava publicamente os direitos de cidadania dos quais se encontrava legalmente privada, gerando-se, assim, efeitos políticos inesperados e mesmo paradoxais, pois a ação política concertada e pública daqueles/as agentes instaurava, em ato e instantaneamente, justamente a cidadania e a liberdade política de que formalmente careciam:

Exercer a liberdade e afirmar a igualdade, precisamente em relação a uma autoridade que as obstrui, é mostrar como a liberdade e a igualdade podem e devem se mover, para além de suas articulações positivas. (...) O chamado para este exercício da liberdade, que vem com a cidadania, é o exercício daquela liberdade numa forma incipiente: ela começa por exercer aquilo que reivindica (BUTLER; SPIVAK, 2010, p. 66-68).

Ali onde a legitimidade do estado é posta 
em questão por uma forma inesperada de aparecimento em público, tais corpos em aliança exercem "um direito que não é um direito", no sentido do direito positivado. Em outras palavras, aqueles/as que lutam e se organizam politicamente exercem um direito que é, também, a constituição ativa de uma forma de vida política. Afinal, por meio desse agir coletivo se

[...] articula seu modo de viver, mostrando tanto sua precariedade, quanto seu direito a persistir. Este direito não está codificado em lugar algum. Não é garantido por nada, ou pela lei existente, mesmo se, por vezes, encontra apoio precisamente ali. Ele é, de fato, o direito a ter direitos, não como direito natural ou como estipulação metafísica, mas como persistência do corpo contra aquelas forças que buscam sua debilitação ou erradicação (Butler, 2015, p. 83).

Não se trata, aqui, de um apelo ao "vitalismo", ou de uma reinvindicação abstrata pelo "direito à vida" (Butler, 2015, p. 83). Trata-se, por outro lado, de corpos que, por sua própria aparição e por sua ação e discursos concertados, colocam em xeque a legitimidade de certos aspectos do ordenamento jurídico estabelecido. Mesmo os corpos expostos à privação e exclusão podem eventualmente tornar-se corpos que aparecem e agem em concerto, ao denunciar sua exclusão do espaço das aparições políticas, e é justamente por meio desse novo modo de aparecer e agir publicamente, que eles põem em ação o direito de que carecem:

Juntos, eles exercem o poder performativo de demandar o público, de um modo que ainda não está codificado pela lei, e que jamais poderá ser totalmente codificado pela lei. E esta performatividade não é apenas discurso, mas são as demandas da ação corporal, do gesto, do movimento, da congregação, da persistência e exposição à violência possível. (...) Tais ações reconfiguram o que será o público e o que será o espaço da política (Butler, 2015, p. 75).

Assim, a interpretação proposta por Butler para o preceito arendtiano do "direito a ter direitos" o entende como lema político. Ele incita à luta por parte daqueles/as que são discriminados/as no interior da comunidade política, assim como por parte daqueles/as que se encontram excluídos/as da comunidade política. Para Butler, como para Arendt, apenas a luta pela conquista de direitos poderá garantir a posse e o usufruto dos direitos, o que, evidentemente, não significa que as duas autoras desprezem o direito positivo, ou desconsiderem a dimensão política do próprio ordenamento jurídico, assim como a importância das reivindicações por direitos humanos, as quais ressaltam sua dimensão moral. Entretanto, como vimos, o núcleo central das reflexões de Arendt a respeito do "direito a ter direitos" é o de que "a privação fundamental dos direitos humanos manifesta-se primeiro, e acima de tudo, na privação de um lugar no mundo que torne a opinião significativa e a ação eficaz" (Arendt, 2000, p. 330). Ora, se a corrosão dos direitos humanos, e de todos os demais direitos, se manifesta em primeiro lugar na condição de estar privado/a da capacidade de agir e discursar politicamente, então, pode-se considerar que a condição primeira para a geração e garantia dos direitos está associada ao exercício da política em atos e palavras, por uma pluralidade de agentes. Pensando com Arendt, para além de Arendt, e mesmo contra Arendt, Judith Butler nos oferece uma interpretação política do "direito a ter direitos”, que faz jus ao brilhantismo da reflexão arendtiana, que continua dando tanto o que pensar nos dias que correm.

Recebido para publicação em 03 de fevereiro de 2020. Aceito em 21 de julho de 2020

\section{REFERÊNCIAS}

AGUIAR, O.: "Hannah Arendt e o direito", Parte II. In Kriterion, n. 143, agosto de 2019.

ARENDT, H. The Jew as Pariah: jewish identity and politics in the modern age. Editadopor Ron H. Feldman, NY: Grove Press, 1978.

ARENDT, H. "Hannah Arendt on Hannah Arendt". In Hill, $\mathrm{M}$. The recovery of the public world. Nova York, St. Martin's Press, 1979.

ARENDT, H. The human condition. Chicago, University of Chicago Press, 1989. 
ARENDT, H. Origens do Totalitarismo. SP: Cia das Letras, 2000. Tradução de Roberto Raposo.

BENHABIB, S. Los derechos de losotros.Extranjeros, residentes y ciudadanos. Tradução de G. Zadunaiski. Barcelona: Gedisa, 2005.

BERNSTEIN, R. J.: "Statelessness and the Right to have Rights", in Hannah Arendt and the Jewish Question. Cambridge, Massachusetts, MIT Press, 1996.

BURKE, E. Reflexões sobre a revolução na França. São Paulo: Edipro, 2014. Tradução de José Miguel Nanni Soares.

BUTLER, J.; SPIVAK, G. C. Who Sings the Nation-State?: Language, Politics, Belonging. Seagull Books, 2010.

BUTLER, J. Notes towards a performative theory of assembly. Nova York: Routledge, 2015.

DUARTE, A. "Judith Butler e Hannah Arendt em diálogo: repensar a ética e a política In: Vida e Liberdade: entre a ética e a política. Curitiba: PUCPRESS, 2016, v.1, p. 311336.
FRATESCHI, Y. "Universalismo interativo e mentalidade alargada em Seyla Benhabib: apropriação e crítica de Hannah Arendt”. In: Ethic@ (UFSC), v. 13, p. 363, 2014.

HONIG, B. "Toward an Agonistic Feminism” in Feminist Interpretations of Hannah Arendt. Ed. B. Honig. Penn State University Press, 1995.

INGRAM, J.: "What is a 'Right to have Rights'? Three images of the Politics of Human Rights". In American Political Science Review, vol. 102, n. 4, Novembro de 2008.

MICHELMAN, F.: "Parsing 'A Right to have Rights"”. In Constellations, vol. 3, n. 2, outubro de 1996.

SCHAAP, A. "Enacting the right to have rights: Jacques Rancière critique of Hannah Arendt”. In European Journal of Political Theory, 10:22, 2011. 


\section{RIGHT TO HAVE RIGHTS AS POLITICAL PERFORMATIVITY: Rereading Arendt with Butler}

André Duarte

This text intends to discuss Hannah Arendt's notion about the "right to have rights", introduced in her analysis of the socio-historical and political elements that later crystalized in the totalitarian domination. In a first moment, I briefly present the original context in which thatArendtian notion was proposed in The Origins of Totalitarianism. In a second moment, I present the way Seyla Benhabib interpreted that Arendtian notion, byemphasizingits allegedly epistemological and moral implications in the context ofa Neokantian cosmopolitanism. In a third moment, I shall argue for a political interpretation of that Arendtian precept, in a clear contrast to Benhabib's reading of it.Finally, in a fourth moment, I present Judith Butler's interpretation of the Arendtian notion about the right to have rights, which emphasizes its political-performative dimension, thus highlighting its importance to understand certain contemporary political movements performed under conditions of deprivation of rights. I conclude that Butler's interpretation is more akin to Arendt's political thinking.

KEY-wORDS: Arendt. Right to have rights. Benhabib. Butler. Political performativity.

\section{LE DROIT À AVOIR DES DROITS COMME PERFORMATIVITÉ POLITIQUE: rélire Arendt avec Butler}

\author{
André Duarte
}

Ce texte se propose de discuter la notion de Hannah Arendt autour du "droit à avoir des droits ", introduit dans son analyse des éléments sociohistoriques et politiques qui se sont cristallisés dans la domination totalitaire. Dans un premier moment, je présente brièvement le contexte original dans lequel la notion d'Arendt était formulée dans Origines du Totalitarisme. Dans un second moment, je présent la manière dont SeylaBenhabib a interprétée cette notion, en affirmant sa portée epistémologico-moral dans le contexte du projet d'un cosmolopolitisme d'inspiration néokantien. Dans un troisième moment je propose une interprétation notamment politique du précepte arendtien, dans un sens divers de celui proposé par Benhabib. Finalement, dans un quatrième moment, je présent l'interprétation du droit à avoir des droits tel que proposée par Judith Butler, laquelle relève sa portée politico-performative et, donc, son importance pour réfléchir sur des mouvements politiques menés à bout dans des conditions de privation de droits. Je considère que la lecture de Butler est plus en syntonie avec la pensée d'Arendt.

Mots-CLÉF: Arendt. Droit à avoir droits. Benhabib. Butler. Performativité politique.

André Duarte - Doutor em Filosofia. Professor do Departamento de Filosofia e do Programa de PósGraduação em Filosofia da Universidade Federal do Paraná (UFPR). Professor do Programa de PósGraduação em Educação da UFPR. Pesquisador bolsista do CNPq 1-C. Diretor da Agência UFPR Internacional entre 2017-2020. Membro do Comitê Gestor do Programa PRINT CAPES-UFPR. Autor de Vidas em Risco: crítica do presente em Arendt, Heidegger e Foucault. RJ: Forense Universitária/GEN, 2010; e O pensamento à sombra da ruptura: política e filosofia no pensamento de Hannah Arendt. SP: Paz e Terra, 2000. Autor de diversos artigos e capítulos de livro publicados no Brasil e no exterior. 
